Apidologie, 1984, 15 (3), 355-358

RAPID COMMUNICATION

\title{
A HIGHLY SPECIALIZED WATER-COLLECTING HONEY BEE
}

\author{
UNE ABEILLE HAUTEMENT SPECIALISEE DANS LA RECOLTE DE L'EAU \\ EINE HOCH SPEZIALISIERTE WASSERSAMMELNDE HONIGBIENE
}

\author{
Gene E. ROBINSON, Benjamin A. UNDERWOOD and Carol E. HENDERSON \\ Department of Entomology, Cornell University \\ Ithaca, NY 14853 USA
}

\begin{abstract}
SUMMARY
While monitoring the foraging behavior of a cohort of individually marked workers we noticed that one bee, Yellow 57 (Y57), took significantly more flights whose duration were significantly shorter and more constant than those taken by other members of the cohort. Y57's unique flight activity suggested that she was either consistently foraging for food at a source close to her hive or collecting water. Inspection of a creek approximatively $0.5 \mathrm{~km}$ from Y57's colony fortuitously resulted in spotting Y57 collecting water. Simultaneous monitoring of the colony entrance and the creek site indicated that Y57 collected water throughout the day and most likely specialized on water collection throughout her 14 day foraging career. These observations confirm that some honey bees do specialize exclusively on water collection.
\end{abstract}

Division of labor in the honey bee colony is age-dependent, with adult workers generally performing discrete sets of tasks as they pass through four temporal castes (SEeley, 1982). Within an age caste some workers perform certain jobs, such as guarding (LiNDaUER, 1952), removing corpses (VISSCHER, 1983) or water collecting (LindaUER, 1952), more frequently than others do, suggesting that they may be specializing to some degree on a single task. However, the extent to which individuals specialize on these tasks exclusively is not known. For example, most foraging workers who collect water do so for only one to two days, but a few workers may be seen engaged in this activity for 
up to 33 days (LindauER, 1952). LiNDAuER suggested that these bees only collected water, but it was not known whether they were also foraging for nectar and/or pollen during the same period. Our extensive observations on the activities of one worker confirm that extreme specialization for water collection does occur.

Yellow 57 (Y57) was a member of a cohort of 150 individually marked workers whose foraging behavior was observed in the course of another study (RoBInSON, submitted). Observations were made for one hour daily at the colony's entrance at various times of the day, between 10.00 and $18.00 \mathrm{~h}$, beginning when the marked workers were 2 days old and continuing for 33 days. The foraging activities of Y57 were monitored for 14 consecutive days (weather permitting), from the first day she was seen foraging, at 17 days of age, until she disappeared at the age of 31 days. During this period Y57 took frequent flights whose duration were shorter and much more constant than those taken by other members of the cohort. Y57 took $7.1 \pm 3.1$ ( $\bar{x} \pm \mathrm{SD}$ ) flights/h, with an average flight duration of $3.5 \pm 0.8 \mathrm{~min}(\mathrm{n}=64)$, while the cohort as a whole took $1.4 \pm 0.5 \mathrm{flights} / \mathrm{h}$ with an average duration of $20.7 \pm 15.7 \mathrm{~min}$. Y57's unique flight activity, noticed by us several days after its onset, suggested that she was either consistently foraging for food at a source close to her hive or collecting water. A scale hive located $50 \mathrm{~m}$ from Y57's colony indicated that relatively little nectar was available during this period. One of us then inspected a creek approximately $0.5 \mathrm{~km}$ from the apiary in which Y57's colony was located (one of several water sources which bees from this apiary could frequent), and fortuitously spotted Y57 collecting water.

On the following day the colony entrance and the creek site were simultaneously monitored for one hour. During that period, Y57's activities closely matched her flight behavior of the previous 14 days. She took 10 flights $/ \mathrm{h}$, all to the water collection site; as indicated above, she generally took $7.1 \pm 3.1$ trips/h. The mean duration of the 10 water collecting trips was $3.3 \pm 0.5 \mathrm{~min}$, virtually identical to the mean duration of all observed flights, $3.5 \pm 0.8 \mathrm{~min}$ ( $p>0.5$; t-test). During each trip Y57 spent about $1.0 \mathrm{~min}$ flying to the creek, $1.1 \mathrm{~min}$ collecting water and $1.2 \mathrm{~min}$ flying back to her hive. She spent $3.9 \pm 3.3 \mathrm{~min}$ in the hive between each flight. Occasional observations made only at the creek site later that day and again on the following 2 days indicated that Y57 collected water throughout the day. Observations were terminated after 3 days of monitoring the water collection site due to Y57's disappearance, which was noted at both the colony entrance and the creek, and confirmed by inspecting the hive's interior. Because her overall flight behavior was extremely consistent and indistinguishable from known water-collecting activity, it is highly probable that Y57 specialized exclusively on water collection throughout her foraging 
career. During the last 3 days of observation, data from the scale hive indicated that nectar had become quite plentiful. Most water-collecting individuals switch to foraging for nectar when it becomes available (LINDAUER, 1955) ; Y57's consistent behavior, despite the availability of new nectar sources, strengthens our conclusion that she was a water collecting specialist.

There have been a few accounts of unusually persistent behavior by individual bees (Lindauer, 1952 ; SaKagami, 1953 ; Meyer, 1956 ; Smith, 1959 ; Winston and Neilson PunNetT, 1982), but our observations on Y57 are the most convincing to date in support of the notion that some workers perform only one task from their age-specific repertoire for long periods of their life. The proximate causes of such specialization are not known, but it is likely that this behavior results in greater efficiency of task performance, as it does for foragers who specialize on particular flower species (HEINRICIr, 1979). Additional studies on the occurrence of highly specialized individuals in all castes are needed to determine whether such individual variation is incidental or a regular feature of the colony's division of labor.

Received for publication in June 1984.

Accepted for publication in July 1984.

\section{ACKNOWLEDGEMENTS}

We thank R.A. MORSE and P.K. VISSCHER for reviewing this manuscript.

\section{REFERENCES}

HejnRich B., 1979. - Bumblebee Economics. Harvard University Press, Cambridge, Mass.

Lindauer M., 1952. - Ein Beitrag zur Frage der Arbeitsteilung im Bienenstaat. Z. vergl. Physiol. 34, 299-345.

LiNDAUER M., 1955. - The water economy and temperature regulation of the honeybee colony. Bee World, 62-72, 81-92, 105-11.

Meyer M., 1956. - «Propolis bees 》 and their activities. Bee World 37, 25-36.

RoBinson G.E. - The effects of juvenile hormone on the ontogeny of honey bee foraging behavior and alarm pheromone production (Submitted).

SAKagami S.F., 1953. - Untersuchungen über die Arbeitsteilung in einem Zwergvolk der Honigbiene : Beiträge zur Biologie des Bienenvolkes, Apis mellifica L., I. Jap. J. Zool, 11, 117-185.

SEeley T.D. 1982. - Adaptive significance of the age polyethism schedule in honeybee colonies. Behav. Ecol. Sociobiol., 11, 287-293. 
SмIтн M.V., 1959. - A note on the capping activities of an individual honeybee. Bee World, 40, 153-154.

VISSCHER P.K., 1983. - The honey bee way of death : necrophoric behaviour in Apis mellifera colonies. Anim. Behav., 31, 1070-1076.

Winston M.L., Neilson Punnett E., 1982. - Factors determining temporal division of labor in honeybees. Can. J. Zool., 60, 2947-2952. 